\title{
Making Sense of The Politics of Recognition: Indicators of Religious Tolerance in Banten, Indonesia
}

\author{
Riswanda, M Dian Hikmawan*, Gilang Ramadhan, Bayu Nurrohman \\ Faculty of Social and Political Science, Universitas Sultan Ageng Tirtayasa
}

ORCID: 0000-0002-9554-8882 (Dian Hikamwan)

\begin{abstract}
This study focuses on the initiatives by the local government that are reflecting the characteristics of the government to be innovative, able to seize opportunities, willing to take risks, and exercising discretion with respect to religious tolerance in Banten. This exploratory research explores how actors in government and in non-government exercised the initiatives on religious tolerance programs in the province regarding the politics of recognition that could be defined in terms of socio-cultural and socio-political perspectives that might help to provide a 'big picture' of the existing intolerance issue. Stigma, labels, and stereotypes have always become difficult challenges to address when it comes to various initiatives advocating religious tolerance in Indonesia. The work and the scale of the authorized government units within the province and other related non-profit based organizations is a high-risk work. The high level of sensitivity and the potential conflict that may be created by false perceptions of such initiatives on the issue makes all the stakeholders must find innovative ways of working all the time, the whole time by considering multi-layered aspects of religious tolerance impacts namely politics, socio-economic and socio-culture approaches interconnectedly. Most of the time, the ability to seize the opportunity, over struggling the meaning of recognition, is needed. The opportunity to create a join-up program involving private and social community groups in creating a greater understanding of religious tolerance services is vital. Also, all the stakeholders need to exercise a certain level of discretion working on this issue. It might be worthwhile to develop frameworks of paying developing multi-lenses forums of religious tolerance to facilitate public hearing centers as a product of the join-up programs. A qualitative approach was chosen to provide insights into the issue by
\end{abstract}

combining non-participant observation, narratives interviews, and small group discussions. This research will analyze how multi-layered aspects of politics of recognition can be found in the work of all the stakeholders in the initiatives on advocating religious tolerance in Banten.

Keywords: Diversity; Tolerance; Recognition; Policy

\section{INTRODUCTION}

The politics of recognition is a form of recognition for minorities. Giving specialties to minorities in uplifting their dignity is an affirmation to give citizens rights. Indonesia as a pluralistic country and built on diversity has challenges in maintaining it. However, recently, several institutions have noted that such as the Setara Institute in Jakarta, there were 216 cases of attacks on religious minorities in 2010, 244 cases in 2011, and 264 cases in 2012. Meanwhile, the Wahid Institute documented 92 violations of religious freedom and 184 incidents of religious intolerance in 2011, up from 64 violations and 134 incidents of intolerance in 2010. (In Religion's Name: Abuses against Religious Minorities in Indonesia., 2013) and there were at least 12 cases of closure of places of worship that occurred in the 2006-2013 period. In protecting the diversity of countries as policy holders have a share in maintaining and caring for differences. However, there are several cases where the government is not present to maintain diversity, such as the case in the City of Cilegon-Banten. This research focuses on several houses of worship which are forcibly closed due to demands from the majority of society. It is interesting that in this study the state should be the guarantor for the fulfillment of citizens' rights. The state, through local governments, is also trapped by policies that exclude minorities by closing houses of worship. 
This research tries to reveal what is happening to diversity in Indonesia. If we look at Indonesia, of course, we cannot see Indonesia in the same light. This means that Indonesia must be interpreted as a difference - the difference is something that is a necessity. In the context of these differences, of course, these differences or diversity must also be interpreted as something that is noble, unique and sacred that must be cared for together. If we look at the table below, it shows that Indonesia has a lot of diversity in terms of ethnicity (Hikmawan, 2017a).

Table 1. Largest Ethnic Groups of Indonesian Citizens:

2000 Census

\begin{tabular}{|c|c|c|}
\hline $\begin{array}{c}\text { Ethnic Group } \\
\text { Number }\end{array}$ & $\begin{array}{c}\text { Number (million) } \\
\cdot\end{array}$ & $\begin{array}{c}\text { Percentage } \\
\cdot\end{array}$ \\
\hline Javanese & 83.8 & 41.7 \\
\hline Sundanese & 30.9 & 15.4 \\
\hline Malay & 6.9 & 3.5 \\
\hline Madurese & 6.7 & 3.4 \\
\hline Batak & 6.0 & 3.0 \\
\hline Minangkabao & 5.5 & 2.7 \\
\hline Betawi & 5.0 & 2.5 \\
\hline Buginese & 5.0 & 2.5 \\
\hline Bantenese & 4.1 & 2.0 \\
\hline Banjarese & 3.5 & 1.7 \\
\hline
\end{tabular}

Source: Indonesia's Population: by Leo Suryadinata, Evi N. Arifin, Aris Ananta, Ethnicity and Religion in a Changing Political Landscape (Singapore: ISEAS, 2003)

Indonesia, where the majority of 85 percent of the population is Muslim, does not have an explicit constitution that gives privileges to Islam as a majority religion, or moreover, it has clauses that can invalidate laws that contradict beliefs in Islam. This is of course different from other predominantly Islamic countries in Southeast Asia such as Malaysia and Brunei which make Islam the state religion and the constitution is regulated based on Islamic law. (Shah, 2018) This proves that the founders of the Indonesian state are committed to making plurality the basis for constituting without benefiting any party. This is the main asset as a pluralistic nation to care for differences and guarantee freedom of belief in Indonesia.

Not only do we mean religious freedom from how big or sophisticated a country is in seeing the diversity of its citizens in numbers, but if we investigate further, religious freedom must also be interpreted by how much citizens can access places of worship which are the rights of their citizens in meet the needs of his convictions. The duty of the state is to provide accessibility for its citizens to be able to access these things. However, recently the social facts that have occurred are quite surprising. The differences in belief and freedom of religion that are guaranteed in the Indonesian constitution cannot easily be accessed by every citizen. Especially regarding access to fulfillment of places of worship. For minority residents, finding or accessing places of worship is a very sensitive issue, especially regarding the difficult construction of places of worship. As quoted in the research (Hikmawan, 2017a) in reading a 2013 report from Human Rights Watch. Prohibition of the Construction of Houses of Worship (Human Rights Watch, 2013)

Between 2018 and 2019 there were at least 31 cases of intolerance that occurred in Indonesia, impartial reported that there were four types of intolerance cases that occurred, including the prohibition and dismissal of religious events and lectures in 12 cases, 11 cases of prohibition of the construction of places of worship, destruction of places of worship, buildings and property in 3 cases, and prohibition of certain cultural or ethnic celebrations in 2 cases. As well as other cases such as the prohibition of wearing certain clothes in accordance with certain religious orders also still occur in Indonesia (Answers.com, 2019). Meanwhile, the Setara institute reported that during 2018 there were at least 160 incidents and 202 actions that could potentially harm freedom of religion and belief. Of the 202 acts of violations of religious freedom, 72 were committed by the state and 130 actions were carried out by non-state, of the 130 non-state actors who committed these violations, the highest was committed by individuals with 46 cases and community groups with 32 cases (Setara, 2018).

In this research, the researcher focuses his research on the case of the prohibition of places of worship that occurred in Cilegon-Banten. But in this research. Researchers focus their research on cases that have occurred recently in the City of Cilegon, Banten. According to BPS 2010 data, Cilegon City has a population of around 374,559 people, the majority are Muslims as many as 364,628 people, are 
Christians as many as 5,857 people, are Catholics as many as 1,425 people, are Hindus as many as 223 people, are Buddhist as many as 1,285 people, and are as many as 21 people from Confucianism. Banten itself according to data from the Ministry of Religion in 2016 has a variety of houses of worship totaling 15,445 houses of worship, including 14,421 mosques, 853 Protestant churches, 35 Catholic churches, 11 Hindu temples, 116 Buddhist temples, and 9 temples. The Ministry of Religion in 2016 also noted that it only had 9 Religious Harmony Forums (FKUB) in Banten, from the dialogue on religious harmony that was facilitated by FKUB in 2016, only 6 cases were in Banten, while the number of facilitations for organizing religious harmony held by FKUB in 2016 there was 1 case.

The prohibition that occurs in places of worship for minority citizens occurs not only because of demands from the domination of the local community with a majority identity but what is interesting in the case in Cilegon City is that there is government interference which should act as a mediator and channel for the aspirations for freedom of its citizens, finally trapped in the case of Cilegon City. the domination of the forcing majority on behalf of the city government also prohibits the existence of places of worship, in this case the Church is located in the City of Cilegon-Banten (Factabanten.co.id, 2017). At least from the initial investigation, we show that there are a number of churches that are banned and forcibly closed by the Cilegon city government.

Table 2. The Curch's Name and Location

\begin{tabular}{c|l|l}
\hline No & Church's Name & Address \\
\hline 1 & Gereja Baptis Indonesia & Jalan Lembang Raya (Link \\
& Rumah pendeta Paul & Tegal Cabe) RT 04/ RW \\
& Kristiyono & 02, Kecamatan Citangkil \\
\hline
\end{tabular}

(Sources: Researcher, 2020)

From this data, this research wants to deepen how recognition can occur in such religious-based conflicts. Of course, tolerance is the initial key in initiating positive energy in response to diversity. However, if tolerance is only interpreted as limited acceptance of differences and diversity but not being able to admit that differences and diversity also includes the right to worship, then we are actually trapped in a kind of discourse of majority tolerance. Where religious tolerance is an artificial thing for minorities because their freedom in religious activities is only within the limits and permits of the majority (Hikmawan, 2017a).

This is of course bad news for religious tolerance activities in Indonesia. Moreover, it is added to the state's position, in this case the Cilegon City government, which is only an extension of majority domination by prohibiting and labeling religious activities as illegal. From this phenomenon, this study actually wants to see patterns and offer new patterns in solving problems of religious tolerance by placing the state as a facilitator who is able to accommodate all existing aspirations so as to minimize exclusion for minority citizens. Therefore, this research wants to try to produce a policy formulation that can be used by the local government, especially the Cilegon City government, in this case to overcome problems based on the issue of religious tolerance. inclusive local government that can accommodate all parties. So, this research will significantly impact the current social conditions that occur in the City of Cilegon-Banten.

\section{LITERATURE REVIEW}

\subsection{The Politics of Recognition}

Recognition is a discourse that is widely discussed in this era. Recognition is a matter that is widely discussed in response to the issue of exclusion of citizens. Iris Marion Young tries to see the problems that are often experienced by minorities in relation to government policies. For (Young, 2000) in Inclusion and Democracy, tolerance is not just acceptance of differences but also our ability to acknowledge all activities that take place because of these existing differences. Furthermore, we are also required to have the ability to recognize activities that may be completely different from our way as long as these activities do not abuse and lead to violence which has a detrimental impact on life together (Hikmawan, 2017b).

In Young's recognition, the specificity in policy is possible as long as the specificity in the policy is useful in enhancing the dignity of citizens, without any exclusion for other citizens (Young, 1990). In Young's understanding, exclusion of citizens often occurs because of work oppressions, this oppression can work ideologically, which means that non-violence is only influencing without coercion and the 
other is dominative where exclusion occurs because of the dominant force of who are both identically, socially, economically and culturally dominant (Hikmawan, 2017b).

\section{Face Oppression by Iris Marion Young (1990) Source: Young (1990}

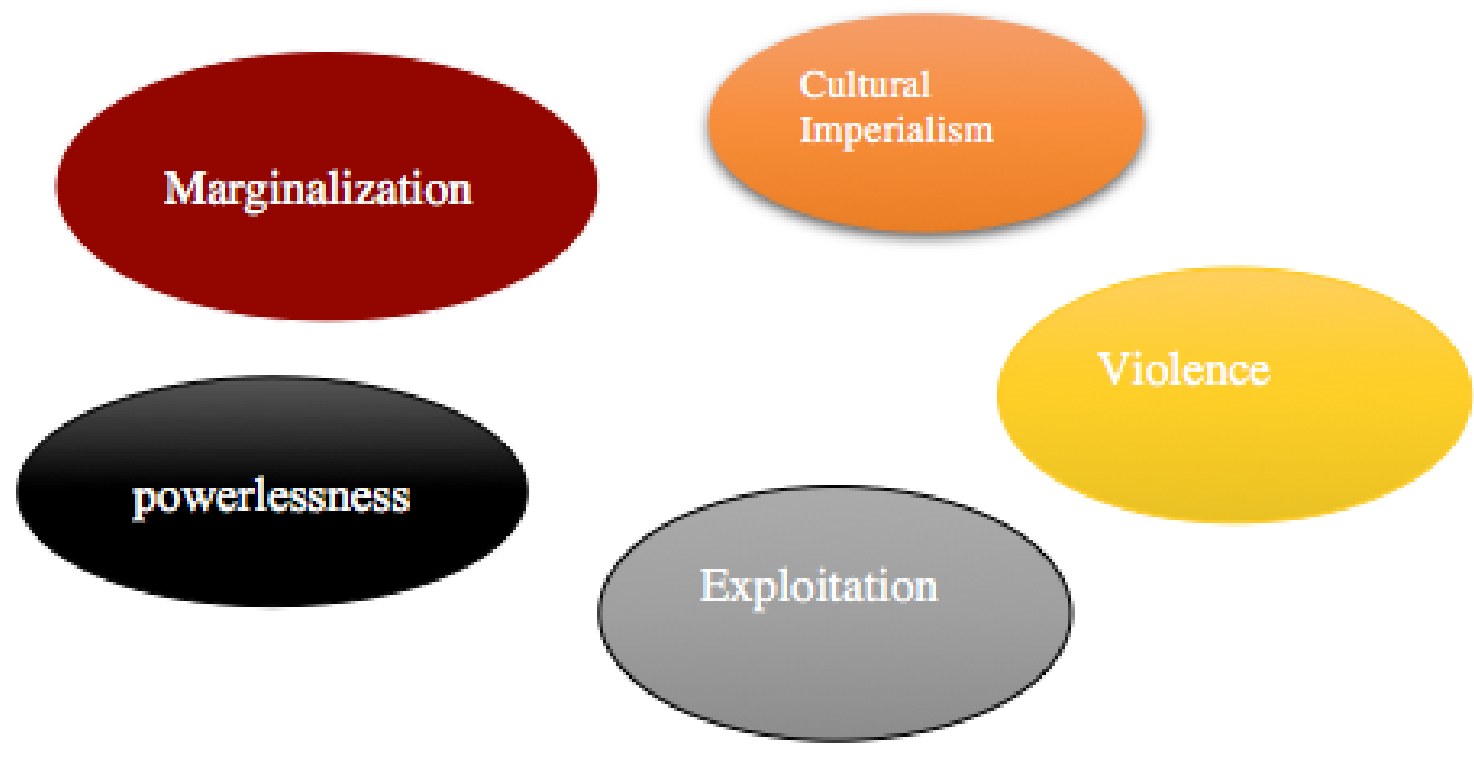

Source: (Young, 1990)

political theory of recognition which was philosophically inspired by Hegel and Honneth. Initially, recognition politics departed from the study of philosophy, culture and identity politics. A prominent philosophical study of recognition was proposed by Hegel (1977). (Douzinas, 2002) The importance of implementing political recognition (politics of recognition) which can be the basis for the creation of togetherness between various cultures, ethnic groups, races and religions. Because the absence of recognition is oppression (misrecognition is an oppression) (Anderson, 2009).

In the demand for recognition, the most important thing is the relationship between recognition and identity, where Cheek (2013) in (Ramadhan, 2018) says that identity orientation refers to subjective values or relative importance that places individuals in various identities, attributes or characteristics formed when they construct definitions. themselves. The fundamental features in the identity structure are the differences between personal identity, one's personal conception of self and subjective feelings of sustainability and uniqueness, and from outside or social identity, one's public image which is generated through social roles and relationships. Meanwhile, Cheek said that social identity is how these individual identities are socialized.

His thesis is that our identities are shaped in part by their acknowledgment or absence, often by the wrong admission of others, so that a person or group of people can suffer real damage, real distortion, if the person or society around them returns to their self-deprecating or derogatory image of themselves. . Ignorance or misrepresentation can be dangerous, can be a form of bullying, and can even judge someone in the wrong way. (Taylor, 2000)

Suharno's writing, entitled Regional Regulations Policy Based on Recognition Politics and Conflict Resolution, is set in the background of the ethnic conflict that occurred in Sampit, Central Kalimantan in 2012. The policy of the Central Kalimantan Provincial Government to overcome ethnic Dayak and Madura conflicts by prohibiting migrants 
from Madura is a preventive measure to avoid continued conflict with the majority Dayak tribe. However, over time the policy was evaluated and a new regional regulation no. 5 of 2004 which brought back conflict-affected residents in Sampit, this happened because Madurese were able to show significant assimilationist attitudes and were not exclusive to the majority population. The politics of recognition emphasizes the good faith of the dominant party to give recognition to those who are legally and legally labeled as a minority or disadvantaged groups.

With this recognition, the rights and positions of minority groups are recognized and can be promoted so that they are equal to the dominant group or only to a certain extent are given recognition. (Suharno, 2012). The emphasis of the political principle of recognition contained in this paper is contained in the Regional Regulation No. 5/2004 on Handling Population Impacts of Ethnic Conflict. This can be seen from its very basic nature, namely the right to live peacefully and reside in Sampit for Madurese as an ethnic minority and in a disadvantaged position. These rights are recognized by the Dayak ethnic group as the majority ethnic group who act as recognition providers as long as the Madurese comply with applicable laws, are willing to participate in upholding the philosophy of "not yet bahadat" and "where the earth is set there the sky is upheld". Meanwhile, the Dayak ethnic group is recognized as an indigenous ethnic group who has a social and social order and customs that are valid and maintained and obliges everyone who comes to respect and uphold these customs as long as it concerns social issues and not religious rituals (Suharno, 2012).

Rian Adhivira Prabowo's writing entitled Axel Honneth's Political Recognition: Its Relevance to the Guarantee of Equality in Law in Indonesia. This paper reveals how the study of recognition politics is in the framework of Honneth's theory, especially in its application in Indonesia. What about the people who were considered related to the PKI in 1965 who experienced disrespect in the whole realm of recognition: their physical integrity was lowered, which resulted in complex psychological problems for the victims and their families. The second case is the politics of recognition in the realm of religious freedom. In addition to creating a distinction between "allowed" and "not allowed" religions, this country's "institutional" approach also creates problems for indigenous peoples. Some of these indigenous peoples' rights have only begun to make significant progress through the fall of the New Order regime. In Law $23 / 2006$ in conjunction with Law 24/2013, the administration has begun to accommodate adherents of beliefs or religions that have not been recognized in population administration records. The latest advancement, the Constitutional Court Decision 97 / PUU-XIV / 2016 made it possible for devotees to include belief in "God Almighty" in the belief column. (Prabowo, 2019).

Prabowo revealed that the biggest challenge is how to accumulate to expand recognition so that it can have a greater impact on solutions aimed not only at the victims, but also for the identity of the new "us". So, these incidents cover all forms of disrespect that were not resolved during the period of transitional justice through legal reform and guaranteeing human rights. The elimination of discriminatory regulations even though they open up space for claims for justice - does not in itself make victims fully equal. (Prabowo, 2019)

Stanisevski's writing, entitled In the Shadows of Nationalism: Social Inclusion and Public Recognition of Roma and Egyptian Identities in Macedonia, describes how two minority groups in Macedonia who are seriously marginalized in social groups, namely the Egyptians and the Romans. The Romans and Egyptians were described by Europeans - for the most part - as nomadic and commonly known as the Gypsies. In Balkan belief, where identity is constructed based on myths from past history, it describes the Gypsies as people who have no permanent residence and are marginalized in the social structure of society.

The social inclusion of marginalized people can lead to intensification of conflicts between cultures and possibly perpetuate their marginalization, which is a possibility when diverse cultural groups come to engage in interaction. Laclau \& Mouffe revealed that the role of government in the politics of social inclusion can hardly be considered neutral, but the role of government cannot be removed to protect minority groups, or a priori against activities that are considered positive and negative in society (Stanisevski, 2008).

Young's conception (Stanisevski, 2008) explains recognition by using symbolic cues showing openness to 
others and recognition of our commitment to listening and taking other cultural differences seriously in the deliberation process. There may also be a need for the inclusion of certain cultural representatives through political mechanisms, such as special representations of marginalized groups. Mc Bride (2005) states that symbolic recognition is very important, but not enough because politics is not limited to the relationship between symbols, but chooses to take collective decisions that can have major consequences for people's lives (Stanisevski, 2008). In addition to presenting symbols as a form of recognition, symbols can also take the form of tolerance, Galeotti (2002) understands tolerance as a positive openness to others, which in itself can be a form of symbolic culture recognition. According to him, the practice of tolerance has a symbolic meaning and shows recognition of differences. Symbolically legitimizing the presence of individuals from certain cultures in the public sphere, in the end these cultural differences will be considered something "normal".

In order to overcome the marginalization of the Romans and Egyptians the Macedonian government took recognition steps to include Romans politically and socially by recognizing them publicly as constituent nations, by providing for the official use of the Romani language and Roman cultural symbols, and by empowering the Roman community with functional and territorial autonomy. to regulate their cultural and regional affairs. Not only recognizing the symbols owned by minorities, the recognition of the majority nation, namely Macedonian and Albanian, is an important key to the recognition process of the Romans and Egyptians. The government also reproduces the identity of the State which has been influenced by the majority culture.

\section{RESEARCH METHODS}

This research is a qualitative research with a phenomenological approach. As a qualitative research, this research tries to give a deeper meaning to the meaning that some individuals or groups of people think come from social, humanitarian and of course environmental problems. (Cresswell, 2013) In order to obtain valid and accurate data, this study will also open as wide a range of possibilities as possible. Phenomenology is used as an approach to be able to better understand how the possibility of understanding all actors involved in the problems studied in this study is revealed and expresses itself so that the understanding obtained becomes comprehensive. Phenomenology allows researchers and those under study to be the same subject so that the inter-subjectivity that occurs can present in-depth data and information (Adian, 2010)

\section{RESULT AND DISCUSSION}

\subsection{Condition of Intolerance in Religion in Cilegon City}

Various rejections to the establishment of a house of worship for Christians in Cilegon City have been going on for quite a long time. Several conflicts always arise along with the spread of news about Christian worship activities in the city of Baja. Conflict in the form of resistance from residents has occurred for a long time, including the Indonesian Baptist Church. There have been more than 10 demonstrations demanding the closure of churches or houses of worship for Christians since 1995.

The Indonesian Baptist Church in Cilegon City actually has legality from the center as well as other regions. However, in contrast to Cilegon, the residents still objected. In 1995 it was recorded that there were four times rejection when the pastor in charge was Uses Sudirman. After that, it was replaced by Pastor Alvius after Sudirman moved to Bekasi, there were still 5 times the rejection of the house of worship even though at that time the location of the house of worship had moved to the Citangkil area, which previously the house of worship was in Gerem, Merak region.

Rejections made by local residents were responded with a conspicuous heart by Pastor Sudirman and Reverend Alvius. They finally heeded the people's refusal so that the worship procession that was carried out had to be hidden from the citizens, even though worship was a basic right for every citizen. It was only in 2017 that a new Pastor appeared who was assigned to be the pastor of the Indonesian Baptist Church in Cilegon.

Different from the story of the previous pastors, Pastor Paul's response in facing rejection actually spurred him to fight for the right to worship which he and his congregation needed. At the time of Pastor Paul, local residents began to quite accept the existence of worship activities from 
followers of the Christian religion. Pastor Paul's activities in social life are very acceptable to the residents. He is a graduate of mechanical engineering, so he created a Vocational Training Center to train local residents and even from other districts to have skills such as the use of lathes, welding, even design. Not only that, he also tried to find work for residents who already had the expertise he had taught so that some residents had worked on his recommendation.

This social activity made Pastor Paul slowly start to be accepted by local people. Unfortunately, the acceptance from the local community has not been able to make Pastor Paul and his congregation able to worship in peace, because some groups are still rejecting the religious activities carried out by the Indonesian Baptist Church. This rejection was brought to the domain of Cilegon City government policy. The response of the Cilegon City Government at that time finally issued a decree prohibiting worship activities at Pastor Paul's house on the grounds that the use of the building was not in accordance with its designation.

But afterwards, Pastor Paul replied to the letter stating that if the building was not in accordance with the designation for worship, then they would continue to worship in the courtyard of the house. Finally, the Mayor allowed the worship process at Pastor Paul's house as long as it was carried out quietly and paid attention to the safety of the residents. Pastor Paul has also taken the administrative processes that need to be fulfilled to hold worship services. More than one hundred signatures were obtained from local residents with a clear statement that they allowed religious services to be held in their area. However, after being taken to the Ministry of Religion, it turned out that what was asked was a signature on a stamp, so Pastor Paul returned to collect it. After it was enough to be submitted, finally the file was brought back but another problem was that it was considered invalid. Several parties who signed were summoned to the Kelurahan (Sub-district Office) and asked about their involvement in the signing of the permit, but unfortunately many residents actually signed but did not confess due to intimidation and various other considerations so that the completed files still could not be submitted.

This administrative process because it cannot be fulfilled, the worship procession is still carried out secretly. Even though in fact, if a lawsuit was filed at the State Administrative Court (PTUN), Pastor Paul was sure he would win his case, Paul chose not to do so because the social impact that would result from the filing would be greater than the pressures he is currently feeling.

Until now, this minority group of Christians still practice their worship independently and cannot hold crowds in celebrating their religious holidays. They still receive pressure, intimidation, and even threats if they are still determined to fight for a place of worship, which is actually their right in religious life in this country.

\subsection{The Government's Role in Overcoming Intolerance in the City of Cilegon}

The Regional Government of Cilegon City has been neutral in dealing with intolerance among religious communities in Cilegon City. Only until now, the Government is still being careful in issuing policies related to permits for places of worship. Pastor Paul actually understands the government's position that is awry, because what is certain to happen if the government issues a permit there will be movements demanding the revocation of permits for places of worship and other objections.

But Pastor Paul still emphasizes the importance of the role of the government in this case, because their existence has actually helped the government's obligations. In terms of education, elementary and middle school students who do not have teachers for Christian students will definitely ask Paul for help to make questions and provide assessments. In terms of marriage and death which are the rights of citizens, the government is also helped because the Indonesian Baptist Church can facilitate the carrying out of the procession in accordance with applicable regulations. So, Paul still hopes for the government's firmness because in our religious life we are always side by side. Especially when Cilegon was expanded from Serang and officially became Cilegon Municipality, in fact it was the obligation of the City of Cilegon to provide public facilities including places of worship which became a basic right for humans to believe and carry out religious activities that they believed to be true. 


\subsection{The Historicity in Creating Intolerace Community: The Roots of the Problem of Intolerance in Religion in Cilegon: Wasiat Ulama}

This story begins during the Dutch colonial period in the land of Cilegon. The concentration of Dutch power in Cilegon caused scars and cynicism that made an impression on the Cilegon community at that time. The dark legacy of the Dutch colonialism at that time created a traumatic feeling for the community / elders in the colonial period. The existence of a traumatic feeling among the Cilegon elders has finally formed the values of intolerance which indirectly shape the attitude of discrimination today. Cilegon elders considered the Dutch to be Christians whose existence had to be expelled from the Indonesian homeland. In the name of religion, a value of intolerance was created in the Cilegon society that continues today. This intolerant attitude was found in the existence of a will from the ulama not to allow the establishment of Christian places of worship in Cilegon City. This will emerge when a Cilegon resident was about to be executed and said one request before he died, the request was not to have a church in Cilegon. Until now, this testament has often been used as an excuse for residents to intimidate Christians in Cilegon with movements such as the Cilegon riot. This doctrine is clearly very strong and has been passed down from generation to generation so that cynicism against Christians from the past to this day still remains.

\subsection{Decree on Church Prohibition in Cilegon City}

The existence of a will of the ulama regarding the prohibition of the construction of churches in Cilegon City, finally the background for the issuance of the Governor's Decree (SK), which at that time was still joining West Java, because it was considered to disturb the local community. Several high-ranking Christian leaders have made several rejections by issuing statements in the form of the anxiety they felt with the issuance of the West Java Governor's Decree. It is considered that this will injure the values of tolerance in religious life, even regarding human rights in belief. For various reasons, Christian officials from the City of Cilegon and the Christian Binmas (Community Guidance) of Banten Province asked this decree to be reviewed. However, the City Government of Cilegon paid no heed to the memorandum

Until now, this Governor's Decree is still used as the basis for some intolerant parties to continue to reject the existence of a church house of worship in Cilegon City. Of course, this decree is a form of intolerance in religious life because it hinders and hinders citizens from carrying out worship in accordance with the religions and beliefs they believe. And Christianity is a religion recognized by the State so that freedom to embrace and practice worship must be guaranteed by the state. Judging from the existence of regional autonomy implemented by Indonesia after reformation, in fact the West Java Governor's Decree could no longer be valid because Cilegon City is no longer part of the West Java Provincial Government, so the position of the Governor's Decree is still very debatable.

\subsection{Unwritten Agreement with PT. Krakatau Steel}

Another root cause of the ban on church worship places is the agreement between the people of Cilegon City and Krakatau Steel. Krakatau Steel was permitted to be built in Cilegon on one condition that it did not provide a church for employees or the community. The consequence is that PT Krakatau Steel has to provide buses every Sunday to take the congregation to Serang City for worship. From the problems found, a solution is needed. That it is not impossible that the powerlessness of religious minorities will lead to new problems. The dividing line between majority and minority religious communities will still exist if not resolved. The intolerant attitude between the people will still exist if there is no solution. In addition, this is not in line with the 1945 Constitution which protects the rights of religious people to worship. In other words, the people in Cilegon City are not yet diverse. Being a minority community does not mean that the right to get public services, in this case a place of worship, is limited and obstructed. It is necessary to instill Pancasila values in a society that pays attention to the freedom of worship for every religious community. This must be realized through the provision of public facilities, namely houses of worship for Christians. Considering the number of religious followers is quite a lot if you have to worship in one place only.

The role of the Cilegon City Government is very important, it needs the realization of the construction of an official church as an effort to fulfill public facilities in the religious sector. Of course, by paying attention to the location of the church construction so as not to disturb the majority Muslim community and trigger tensions between religions. Reflecting on this situation, the government must be careful 
so that there is no friction or even division between religious communities. Licensing must pay attention to the function and location of the construction of the Church. If the reason for not establishing a church is due to Christian religious activities which are considered disturbing, then the construction of a church can be established in an area that is far from residential areas of the majority Muslim community. Like the construction of a church that was built around the Cilegon City Government office area. Then if the reason for not establishing the church is due to historical history, the government must provide an understanding of the values of tolerance. And again, Christians in Indonesia, especially in Cilegon, are not invaders who must be fought, but are domestic brothers. So, the majority society can become the protector of the minority community without limiting the rights owned by all citizens.

Pancasila as the basis of state ideology has not been perfectly implemented in social life in society. This is because there are still many layers of society who have not directly felt the benefits of the implementation of Pancasila. There are still many failures to implement Pancasila, especially in cases of discrimination against minority groups. One of them is in the form of religious discrimination against Christians in Cilegon which is against the implementation of Pancasila. The state gives full freedom to citizens to embrace and practice their religion according to their wishes without exception. So that there should be no discrimination against certain religions with different beliefs, because Indonesia is a country devoted to six official religions that coexist; Islam, Protestant Christianity, Catholic Christianity, Hinduism, Buddhism and Confucianism. From the understanding of this first principle, it is not wrong for Christians in Cilegon to worship anywhere, and it is not a violation of the law. So that there should be no discrimination by certain groups.

So, it is appropriate for all levels of society regardless of the minority or the majority to always uphold the basic values of the five principles of Pancasila to be applied in daily life, in order to create harmony in society and the state. With the awareness of the importance of upholding Pancasila, it will result in a safe, peaceful social life and a sense of love among fellow Indonesian citizens both in the majority and minority groups.

\subsection{The Politics of Recognition}

In essence, all multiculturalist political movements are a form of struggle for recognition. In a part like this the politics of recognition, referring to opinion (Taylor, 2000) is a human need for its existence. Matters like this need to be understood by recognizing the identity of all human beings that they need to be seen with equality and equality without any form of discrimination.

Taylor then argues that the politics of recognition can be viewed from two different points of view. The first is to interpret how all human beings need to get the same recognition in any case including social, religious, and legal aspects. The second thing Taylor sees that every human being needs to be recognized in his diversity, that every human being has differences and that is where his uniqueness is. So, every human being also needs recognition in the diversity they have.

Taylor's conception is one of the tools of analysis in seeing the condition of religious intolerance in Cilegon City which is still ongoing. The city of Cilegon, which is better known as the city of steel or the city of industry, still has stories of religious intolerance in its social life. Rejection of the construction of a church house of worship, efforts to disband the worship procession, celebrating a big day in a crowd, and other things are still a matter of diversity that has not been completed in Cilegon City.

\subsection{Conquest of Houses of Worship}

If we look at what happened in the conquest of places of worship that occurred at the GBI church in Cilegon, we can see several variables that make why this happened. In the simplest conception of a state, the state must always be a neutral party capable of facilitating all the interests of its citizens. In this case the need for a place of worship (Hikmawan, 2017a). The simplest conception should be present in the conflict prohibiting places of worship that occurred at the GBI church in Cilegon city, but what happened was that the government seemed to be held hostage by the wishes of the majority in the name of security and order. This is what makes the state lose its role in overcoming equality of public access for every citizen.

The defeat of the state to the will of the majority is a sign that democracy currently stands for majority democracy over minorities (Hikmawan, 2020). This also bodes badly for the existing state of democracy. The state loses its role as the party that has the most authority in distributing equality and equal access for every citizen. In view 
(Hikmawan, 2014), actually a model of democracy that rests on majority decisions, is a pseudo democracy where democracy is not built on egalitarian grounds or freedom of respect for individual freedom, but majority democracy is only built on agreement or agreement from groups who feel they have power over individual freedom. the duration of that power. The state becomes co-opted by majority power and the role of the state seems to have been replaced by majority power (Hikmawan, 2017a).

\subsection{Democracy: From Consensual to Multicultural}

In such a conception, minorities such as the GBI Church case in Cilegon City is just one of many other cases in Cilegon City. The concept of a multicultural state (Kymlicka, 1995) (Kymlicka, 2011) (Kymlicka \& He, 2005) actually provides an opportunity for the development of a more tolerant social life in society (Banting \& Kymlicka, 2013) (Kymlicka \& Norman, 2000). Where the state has an important role in realizing a multicultural state life. But at the same time the big point of Kymlicka is simply the extent to which society can be built within a sphere of tolerance. This also often means that tolerance is only to the extent that the majority is able to give freedom to those outside themselves but still under the control of the majority power (Hikmawan, 2017b). This also makes tolerance an artificial thing for the realization of multicultural diversity because it is trapped in hierarchical power (Hikmawan, 2017b).

The conception (Young, 1990) in realizing a multicultural society actually explores how the roots of coercive power exist and develop. In addition to his explanation of the models of operation that take place in the social life of society (Young, 2000) (Appiah, Benhabib, Young, \& Fraser, 2007). Furthermore, Young actually refers to Taylor's conception of choosing the path of recognition as an effort to create a multicultural community life (Vieten, 2018). Apart from analyzing how surgery and violence work in our society's systems. Young offers a concept of differentiated citizenship as a discourse in understanding multicultural society (Young, 2011). In addition, (Fraser \& Honneth, 2003) views that a multicultural society can only be built from an egalitarian redistribution of power and recognition of differences. Recognition is not only limited to passive recognition, but recognition is the ability to fight for an egalitarian and equal society in gaining public access. The table below can simplify how the consensual democracy model works with a multicultural model.

Table 3.

Democracy in Comparison Between Consensual and Multicultural

\begin{tabular}{|c|c|}
\hline Consensual Democracy & Multicultural Democracy \\
\hline - $\quad$ a state agreement at the will of the majority & Difference is a necessity \\
\hline - $\quad$ majority agreement is the avenue for political & - $\quad$ respect for differences in identity \\
\hline decisions & - $\quad$ have the ability to recognize existing differences. \\
\hline - $\quad$ general rationality becomes a political decision & - $\quad$ Respect for the uniqueness of every citizen \\
\hline - $\quad$ the model of consensual democracy - deliberative & Political decisions are based not only on rationality but \\
\hline (Habermas J., 1996) & also considering the existing diversity \\
\hline \multirow[t]{6}{*}{ Monological in a democracy where majority } & A-symmetrical Democracy Model \\
\hline & - $\quad$ Differentiated citizenship ((Young, 1990) where every \\
\hline & citizen is always considered to be different and \\
\hline & mutually constitute one another \\
\hline & - Dialogic democracy is always re-articulated within the \\
\hline & sphere of recognition and tolerance \\
\hline
\end{tabular}

Source (Hikmawan, 2017a, 2020) 
From what we understand in the case of the prohibition of places of worship that occurred in Cilegon, with all the roots of historicity that are still being built in the superiority of identity. It shows that the practice of consensual democracy which relies political decisions in the state on the decision of the majority, in the end, excludes other citizens who have differences with what is the decision of the majority. Cooptation of the state is also crucial where the state is unable to attend and provides equality for its citizens. The concept of a state has been replaced by the consensus model of the majority group.

The conception of a multicultural society is not a very easy thing to realize. From what we can get in the case of religious freedom in Cilegon. that the roots of the exclusivity of the majority group are not only built from the identity of the majority alone, but also the long historicity factor that was tried to be built as a common fantasy that made the majority group stronger in rejecting diversity. Awakening the historicity of this superior identity which leads to intolerance and exclusion of minority citizens.

Recognition when we refer to (Young, 1990) (Fraser \& Honneth, 2003) is a struggle that has become a discourse together. In this case, recognition is an "ability" in fighting for diversity which is considered a necessity (Young, 1990). This "ability" must also be able to manifest in various people's lives. The state must have "Ability" in creating an inclusive policy. Each group of citizens must also have the "Ability" in placing themselves in the same position as citizens and be able to realize diversity as a necessity and something that is givenness (Hikmawan, 2017a, 2020).

\section{CONCLUSION}

The prohibition that occurs in places of worship that occurs in the city of Cilegon is basically a general description that occurs in many places in Indonesia. This actually makes us have to rethink the democratic system and how we will interpret democracy that should develop in the government system. On the one hand, the state must strengthen itself and take an important role in distributing equality for every citizen. On the other hand, the social life of our society must also discuss how multicultural life is built on the basis of respect for differences and diversity.

This research has actually elaborated that the complex problems that occur in diversity and diversity have different roots. Starting from the rise of ethno-nationality and the exclusivity of a group to the rise of fanaticism against the historicity of the past that seems to generate superior identity and forget about the diversity of identities. Of all the things that can be described in this research, there is actually still a point on how to overcome inequality in equality of religious freedom. At least this research also offers how the state must be able to take a role and be able to discourse the concept of multiculturalism in overcoming the hidden majority power in consensual democracy. In the end, diversity and respect for differences can only be achieved if all parties, both the state and citizens, are able to define all the diversity, uniqueness and differences in dialogical types that are able to recognize without violence and the decisions of a group of parties.

\section{Acknowledgment}

The researcher's gratitude to Universitas Sultan Ageng Tirtayasa for all the funding of this research. We also thank to all informants and organization who contribute to all data and access to make this research proper.

\section{References}

[1]. Anderson, S. C. (2009). Hegel's Theory of Recognition: From Oppression to Ethical Liberal Modernity. Continuum.

[2]. Appiah, K. A., Benhabib, S., Young, I. M., \& Fraser, N. (2007). Justice, Governance, Cosmopolitanism, and the Politics of Difference: Reconfiguration in a Transnational World. Distinguished W.E.B. Du Bois Lectures. https://doi.org/10.1039/c3an02113k

[3]. Douzinas, C. (2002). Identity, Recognition, Rights or What Can Hegel Teach Us About Human Rights? Journal of Law and Society, 29(3), 379-405. https://doi.org/10.1111/1467-6478.00225

[4]. Fraser, N., \& Honneth, A. (2003). Redistribution Or Recognition? https://doi.org/10.1111/j.1095-8649.2009.02189.x

[5]. Habermas J. (1996). Between Fact and Norm Contributions to a Discourse Theory of Law and Democracy. (R. William, Ed.). The MIT Press.

[6]. Hikmawan, M. D. (2014). Politik Perbedaan Demokrasi dalam Paradoks. Universitas Gdjah Mada.

[7]. Hikmawan, M. D. (2017a). Pluralisme Demokrasi Politik di Indonesia. Journal of Governance, 2(2), 223 247.

https://doi.org/http://dx.doi.org/10.31506/jog.v2i2.2678 
International Journal of Engineering Research and Technology. ISSN 0974-3154, Volume 13, Number 11 (2020), pp. $3386-3397$

(C) International Research Publication House. https://dx.doi.org/10.37624/IJERT/13.11.2020.3386-3397

[8]. Hikmawan, M. D. (2017b). Politik Perbedaan: Minnoritas dalam Implementasi Kebijakan. Journal of Indonesian Public Administration and Governance Studies (JIPAGS), 1(1), 88-98.

[9]. Hikmawan, M. D. (2020). Consensual Democracy: A Challenge for Differentiated Citizenship. International Journal of Innovation, Creativity and Change. www.ijicc.net (Vol. 11). Retrieved from www.ijicc.net

[10]. http://faktabanten.co.id/2masyarakat-bersama-pejabat-p emkot-cilegon-resmi- menutup-gereja-ilegal-di-citangki

[11]. https://www.jawaban.com/read/article/id/2019/11/18/9 1/191118153643/selama_setahunintoleransi_di_indone sia_sudah_mencapai_31_kasusmengkhawatirkan

[12]. https://setara-institute.org/setara-institute-ada-202-pela nggaran-kebebasan-beragama-selama-2018/

[13]. Human Rights Watch, In Religion's Name: Abuses against Religious Minorities in Indonesia. (2013).

[14]. Kymlicka, W. (1995). Multicultural Citizenship A Liberal Theory of Minority Rights. Oxford University Press.

[15]. Kymlicka, W. (2011). Multicultural Odysseys: Navigating the New International Politics of Diversity. Oxford University Press. https://doi.org/10.1163/174552411x549327

[16]. Kymlicka, W., \& He, B. (2005). Multiculturalism in Asia. Multiculturalism in Asia. https://doi.org/10.1093/0199277621.001.0001

[17]. Kymlicka, W., \& Norman, W. (2000). Citizenship in Diverse Societies. In W. KYMLICKA \& W. NORMAN (Eds.) (p. 457). Oxford University Press.

[18]. Retrieved from https://www.hrw.org/sites/default/files /reports/indonesia0213 ForUpload 0. pdf

[19]. Prabowo, R. A. (2019). Politik Rekognisi Axel Honneth: Relevansinya terhadap Jaminan Kesetaraan dalam Hukum di Indonesia. Jurnal Ilmiah Ilmu Pemerintahan, 4(2), 75. https://doi.org/10.14710/jiip.v4i2.5379

[20]. Ramadhan, G. (2018). Identitas Dan Gerakan Sosial Di Rumpin. Polinter, 3(2), 1- 11.

[21]. Shah, Dian A.H. (2018). The Law and Politics of Religion and Constitutional Practices in Asia. Asian Journal of Comparative Law. 13. https:// doi.org/10.1017/asjcl.2019.3

[22]. Stanisevski, Dragan, M. (2008). In The Shadows of Nationalism: Social Inclusion and Public Recognition of Roma and Egyptian Identities in Macedonia. Public Administration Theory Network, 30(4), 476-495.

[23]. Suharno, S. (2012). Kebijakan Peraturan Daerah Berbasis Politik Rekognisi dan Resolusi Konflik Etnik. Informasi, $38(2)$. https://doi.org/10.21831/informasi.v2i2.4449

[24]. Taylor, C. (2000). The Politics of Recognition.
Proceedings - IEEE International Symposium on Circuits and Systems (Vol. 1). https://doi.org/10.1109/iscas.2000.857208

[25]. Vieten, U. M. (2018). Revisiting Iris Marion Young on Normalisation, Inclusion and Democracy. Palgrave. https://doi.org/10.1057/9781137440976.0001

[26]. Young, I. M. (1990). Justice and the Politics of Difference Iris. PRINCETO N UNIVERSIT Y PRES S. Princeton University Press. https://doi.org/10.1016/S0889-8588(05)70468-8

[27]. Young, I. M. (2000). Inclusion and Democracy. Oxford University Press. Oxford University Press.

[28]. Young, I. M. (2011). Responsibility for justice. (SAMUEL FREEMAN, Ed.). Oxford University Press. https://doi.org/10.1017/CBO9781107415324.004 